\title{
U.S. Marketers Play Catch-Up With Text-Message Marketing Usage
}

\author{
Traci Warrington, (E-mail: traciwarrington@salve.edu), Salve Regina University
}

\begin{abstract}
While the use of text-message (or SMS) marketing is widely used in marketing campaigns in countries like Singapore, China, England, and Norway, U.S. marketers have been slow to adopt this new technology. As text message use increases in the United States marketers are beginning to explore its use as part of the marketing communications mix. Marketers are finding text-message marketing a valuable direct marketing tool that can be used to send one-way or two-way communications that aid in direct response marketing and database development. From providing in-the-moment data such as driving directions, located-based promotions, movie times and such to building excitement, viral communications, and brand recognition through two-way communication, text-message marketing has value. This paper examines the use of text-message marketing, reasons for slow adoption in the U.S., and the future of text-message marketing in the United States.
\end{abstract}

\section{TEXT-MESSAGE MARKETING}

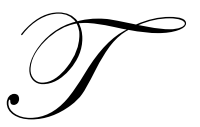

ext messaging refers to sending short messages - usually no more than 160 characters of data - to a cellular phone, pager, PDA or other handheld wireless device. These text messages may be generated by another cellular phone - which is generally the case for interpersonal communications - or by a special email address which has the ability to send commercial messages to multiple phones (Text Messaging, 2005). Text messaging is also referred to as Short Message Service (SMS) marketing. "Short messages are stored and forwarded at SMS centers, which means you can retrieve your messages later if you are not immediately available to receive them" (SMS, 2005).

Marketers can use text-message marketing in either a push or pull advertising format. The push format sends unsolicited messages; while the pull format adds messages to content the user has requested. This requested content may include traffic reports, weather, sports scores, or similar content. As with email and other media, users tend to respond more favorably to pull strategies, and often refer to push strategies as spam.

Marketers are finding text messaging a valuable direct marketing tool that can be used to send one-way or two-way communications that aid in direct response marketing and database development. Table 1: Text-based Communications depicts the one-way versus two-way communications usage with text messaging. The two models differ in the party who initiates the communication and in the overall involvement in the communication. The twoway communication model is interactive; where the one-way communication model is informative. The one-way communication's value is in reminding the consumer of the brand. For example, the one-way communication model may be used to remind consumers to take a certain medicine. The consumer's cellular phone would beep indicating a text message. The message would remind the consumer to take the medicine, and may provide other valuable information about the brand or other related products. No response is required by the consumer. This is generally a model in which consumers would "opt-in" to receiving the weekly text message reminder. The user's response to the company's communication in the two-way model is more valuable in terms of database development and as a response device. The two-way model would require the consumer to respond to a communication via text messaging. That communication could result in a sale, more information, scheduling appointments, or other similar tasks. 
Table 1

Text-Based Communications Models

One-Way Communication

Communication Model:

Example:

Provides:

Two-Way Communication

Communication Model:

Example:

Provides:
User Requests Information $\rightarrow$ Company Sends Information

User Requests Weekly Reminder $\rightarrow$ Company Sends Weekly Reminder

Information
Company sends Communication $\rightarrow$ User Responds via Text Message $\rightarrow$ Info Updated TV Ad with Text Response Device $\rightarrow$ User Texts Info $\rightarrow$ Company Updates User Info Interaction with consumer

Responses to text messages tend to be fast - especially when targeting a younger audience. “..70\% of responses to text-message marketing come within 24 hours, and $90 \%$ within 48 hours, according to Wolverhampton, England-based Mobile Data Association" (James, 2002). Text-message marketing also provides the opportunity for marketers to acquire consumer data to add to the company's current database.

Another reason for the favorability of text-message marketing is that marketers utilizing text messaging as part of their marketing campaigns report high response rates. Response rates as high as $31 \%$ have been reported (Dickinger, Haghirian, Murphy, and Scharl, 2004). Start Corporation in South Africa reports response rates of 25\% and above for its overseas clients (Direct marketing with unique interactive SMS system delivers response rates of 25\% and more, 2004). The Marketing News reports response rates between 5\% and 50\% for text-message marketing (James, 2002). The Economic Times (2004) reported an average response rate of $15 \%$ in the UK according to company Enpocket (SMS marketing yields 15\% response, 2004). The Economic Times also went on to note that $20 \%$ of cell phone users show a text message to a friend. This viral component adds to the desirability of SMS use especially among younger users who are strongly influenced by peers.

The viral characteristic of text messaging is also mentioned on Brainstorm's website (an SMS marketing agent). Unique features and advantages of text-message marketing mentioned on the web site include "response rates over $10 \%$, recall rates of over $75 \%$, stronger ROI case than other media, ....immediate 'brand in hand,' 2 -way: Dialogue with consumer, targeted..., cross media: mix with radio, TV, print, viral: consumers forward messages, and fun: $1.2<$ billion> messages sent per month" (SMS Marketing, 2005).

These advantages fuel the rising use of text-message marketing globally. In an increasingly mobile society marketers seek ways to reach that out-of-home consumer. Lowry (2001) notes that "..Consumers are out of their houses $65 \%$ more than they were two decades ago." This suggests that we can no longer count on reaching consumers in their living rooms, as has been the case previously. Marketers must now look to reach consumers on the go. The "brand in hand" characteristic presents great current and future opportunities to build brand awareness, improve timeliness of promotions and information, and aid consumers in managing information in the marketplace. The opportunity to conduct a two-way communication with the consumer also provides occasions to acquire data to improve databases, build trust, and present personalized messages to users.

The popularity of text messaging varies widely globally. Wireless users in countries such as Singapore, China, Japan, and the United Kingdom are using text messaging much more than U.S. wireless users. The Economist (2003) reported 247 text messages per mobile subscriber sent or received per month in December 2002 in Singapore; 198 in the Philippines, over 60 in Norway, and more than 30 in the United Kingdom (No Text Please, We're American, 2003). Mobile subscribers in the United States send or receive less than 10 text messages per month. The proliferation of use in these other countries has led to much greater use of marketing via text messaging. As text message usage rates increase in the United States, marketers will begin to play catch up in SMS marketing. 


\section{U.S. MARKETERS CATCHING ON}

Text messaging in the United States has not enjoyed as much success as in countries like the UK. With fewer personal text messages being sent in the U.S., marketers have been reluctant to integrate its use into the overall communications mix. Even though usage is still relatively low, text messaging is increasing in the United States. As the incidence of text messaging increases marketers will be more likely to explore its use.

"In December 2000, we counted 14.4 million SMS messages in the U.S. One year later, SMS traffic had jumped from 14.4 million messages to over 252 million messages. And by December, 2002, SMS traffic in the United States grew over four-fold from the 252 million messages a month the year before, to more than a billion messages a month" (Altschul, 2003). He further noted that even though only $20 \%$ of U.S. wireless customers were sending text messages, $45 \%$ of 18 to 24 year olds were using the text-messaging feature on their phone. Altschul (2003) goes on to say, "..We believe peer-to-peer SMS traffic in the United States is poised to take off." The Economic Times (2004) reported 930 million text messages per month in the US in 2002, growing to 1.2 billion per month in 2003. According to Yuan (2005), 4.7 billion text messages were sent in December 2004. The growth of text messaging in the United States from various sources is compiled in Table 2 below.

Table 2

U.S. Growth Of Text Messaging

\begin{tabular}{|c|c|}
\hline Year & Text Messages Sent Per Month \\
\hline 2000 & 14.4 million (Source: Atschul 2003) \\
\hline 2001 & 252 million (Source: Atschul 2003) \\
\hline 2002 & 930 million (Source: Economic Times 2004) \\
\hline 2003 & 2.1 billion (Source: Yuan 2005) \\
\hline 2004 & 4.7 billion (Source: Yuan 2005) \\
\hline
\end{tabular}

The growth of text messaging in the United States is impressive. Still Yuan (2005) calls the United States a "laggard in texting." CTIA (the Wireless Association) compares text use in the United States where wireless users send 203 text messages on average to China where wireless users send 651 text messages on average. The slow adoption of text-message marketing in the United States is due to several important factors. These factors include incompatibility between phone networks, penetration of Internet-enabled cell phones, and the need to pay for incoming text messages. In many European countries text messaging is cheaper than phone use, and incoming text messages are free (James, 2002). ATKearney (2001) reported 72\% penetration of Internet-enabled cellular phones in Japan, $45 \%$ in Europe, and only $25 \%$ in North America (Mobinet Index \#3, 2001). Differences in the adoption rate of the technology are partially responsible for the U.S. lag in text-message marketing. It has only been in the last few years that wireless users on different networks could send and receive text messages to one another.

Ad Age recently reported that although U.S. marketers are now discovering the third screen and companies such as Coca-Cola, McDonald's, Heineken, Nesquik, and Starburst are exploring its use, "marketers are increasingly interested in mobile marketing, but the agencies aren't (yet) there to help them and provide ideas and resources" (Marketers Discovering the "Third Screen," 2005). This third screen refers to wireless mobile devices such as cellular phones, beepers, and PDAs.

Other companies exploring the use of text-message marketing in the U.S. are Kraft and the Backstreet Boys. Kraft recently reported efforts to integrate text messaging efforts into its marketing mix in the United States. In July 2005, Kraft offered consumers the ability to download 100 recipes into the Notes area of Apple's iPod. Kraft recognized that consumers are out of the home and away from their Internet connections more often, and was seeking a way to reach them out of the home. Ian Smith, Director of Global Digital Marketing at Kraft said, "Whether through iPods, cell phones, Blackberry's or PDAs, you're going to see these new media get a lot more attention from us in the future" (Thompson, 2005). This goes back to the idea of "brand in hand." The ability to reach consumers anywhere anytime has enormous value in our mobile age. 
The Backstreet Boys have found a use for commercial text messaging as well. Beginning with their summer 2005 concert tour, fans in attendance could send text messages to the overhead screens that appeared during the show. Fans were charged \$2.99 per text message. Messages were edited to prevent offensive messages from showing on the screen. During the first three weeks of use, the text promotion generated more than $\$ 25,000$ for the band (Newcomb, 2005). Similar versions of the technology used by the Backstreet Boys have been tested for use at Los Angeles Angels baseball games at Anaheim, and at the Times Square billboard. This use demonstrates the value of two-way communication in the overall consumer experience. These text messages made the fans feel more connected to the band and improved their overall experience at the performance.

\section{THE GROWTH OF SMS ABROAD}

As previously noted, text messaging is used more widely in countries such as Singapore, the United Kingdom, and China. In Canada, Rendon (2004) noted the CWTA (Canadian Wireless Telecommunications Association) reported a $300 \%$ year-over-year increase in the volume of text messages since 2002. Canadian cell users send an average of 37 million text messages each month. Asia and the UK report even higher numbers of text messaging. The Mobile Data Association in the UK reported 1.9 billion messages sent per month (Rendon, 2004). The average number of text messages transmitted per month globally per subscriber is 30 , but in the U.S. it is only 7 (No text please, we're American, 2003). India also sees growing use of SMS technology. Srinivasan (2004) reports more than 33 million wireless subscribers, and growing by two million per month. With such penetration of wireless technology, companies such as Coca-Cola, L'Oreal India, and Standard Chartered Bank have been using SMS promotions to reach targeted audiences. Each of the companies mentioned the ability to personalize their messages and to reach consumers directly as benefits of this technology.

Growth of daily text messaging in the UK, as reported by the Mobile Data Association, has moved "from 19 million in 2000, to 36 million in 2001, to 48 million in 2002, and 58 million in 2003" (SMS marketing yields 15\% response, 2004). Most recently in a press release dated August 23, 2005 from the Mobile Data Association, text messaging in the U.K. rose to 2.7 billion messages in the month of July 2005 - the highest total ever recorded for one month. On average, 87 million text messages were sent per day - a $23.5 \%$ increase in person-to-person texting over the same period last year (100 Billion Messages Sent by UK's Texting Generation as Texting Hits All Time High, 2005). Each new month seems to bring a new high, as record highs were reported in May and June 2005 as well (May Makes Way for All Time Top Text Total, 2005). Although increases in person-to-person texting are partially responsible for these new highs, increased usage of text-message marketing is also attributed. During Summer 2005, promotions by such organizations as BBC Radio 5 Live, Wimbleton and Teletext, fashion designer Ted Baker, and Yahoo UK - just to name a few - are also driving text figures upwards. From the latest Wimbleton scores, match times, voting for the best cricketing moment of the summer, or receiving pollen updates, consumers are finding text messaging one way to keep up-to-the-minute in news and happenings (May Makes Way for All Time Top Text Total, 2005).

Examples of text-message marketing use as integrated into the communications mix are plentiful outside of the U.S. Several examples of recent successful efforts follow and show the varied use of the new media type. In the United Kingdom, Peugot recently launched a television commercial with the only call to action being text messaging. By texting the word "easy" to 81007 , respondents could receive more information, book a test drive, order a brochure, download screensavers and ringtones, and more (TV Ad Text Response, 2005). Peugot's campaign came on the heels of what is believed to be the first use of text message responses in television advertising by a car manufacturer in January 2005. DaimlerChrysler's Smart UK used text message response to their television commercial to allow respondents to arrange test drives, request brochures or locate dealers (Smart Claims a First for Text Message Response System to TV Advertising, 2005). DaimlerChrysler's Smart UK was responding to "new research that indicates that SMS is consumers' preferred method of responding to TV advertising, as it takes seconds and does not interrupt viewing" (Smart Claims a First for Text Message Response System to TV Advertising, 2005).

Warner Home Video launched an SMS marketing campaign to consumers in France who were able to use text messaging to download Harry Potter ringtones and logos in an effort to promote the launch of the new DVD "Harry Potter and the Prisoner of Azkaban" (SMS campaign for launch of Harry Potter DVD in France, 2004). In a 
similar effort, in January 2005, Madonna promoted her newly released album to fans via SMS. Following a blast to their cell phones, fans could preorder her album by pushing "1" on their cell phones to connect to a live operator to place their order (Mobile marketers turn to live assistance, 2005).

New Media Maze recently launched a viral marketing campaign via text messaging to promote the release of the horror film The Ring Two on DVD. Visitors to the DVD website can enter friends' email addresses and cell phone numbers. The email invites the receiver to visit the DVD website and watch a video. While they are watching it, their cell phone rings and a voice whispers "Seven days" into the phone. The viewer then has the option of sending the viral to five of their friends. The viral campaign is being billed as one of the scariest ever (Horror Film Viral Sends Victims Phone Message, 2005).

Through these examples one can see the opportunity to become part of the consumer's life, rather than just intrude upon it. In this way the marketer talks with the consumer instead of at them. The uses of text-message marketing in these examples show how this new media promotes two-way communication and adds value to the overall consumer experience.

\section{TARGETING USERS}

There is no doubt that text messaging tends to be more attractive to the young. According to McGann (2005), 18-27 year olds are the widest users of text messaging. This Generation Y group shows significantly higher usage of text messaging than the closest older age group, Generation X. Table 3 demonstrates text messaging use by generation in the United States. As Table 3 demonstrates, text message use declines with age. Generation $\mathrm{Y}$ is the largest user of text messaging, with $63 \%$ using the technology. In contrast, only $31 \%$ of Generation $X$ and less than $20 \%$ of Baby Boomers use the technology (McGann, 2005).

Table 3

Text Messaging Use By Generation In U.S.

\begin{tabular}{|c|c|}
\hline Generation & \% Using Text Messaging \\
\hline Generation Y & $63 \%$ \\
\hline Generation X & $31 \%$ \\
\hline Baby Boomers 40-49 years old & $18 \%$ \\
\hline Baby Boomers 50-58 years old & $13 \%$ \\
\hline Over 60 years old & $7 \%$ \\
\hline
\end{tabular}

Source: McGann (2005)

Brainstorm reports $69 \%$ usage of SMS by all adults in the United Kingdom. The website further breaks down use by UK residents as $87 \%$ of $15-24$ year olds, $85 \%$ of $25-34$ year olds, $83 \%$ of $35-44$ year olds, $73 \%$ of $45-54$ year olds, $61 \%$ of $65-74$ year olds, $43 \%$ of $65-74$ year olds, and $15 \%$ of $75+$ year olds (SMS Marketing, 2005). When compared to U.S. usage figures in Table 3 above, the U.S. population significantly lags behind the U.K. in text message usage, especially among older adults. U.S. adoption of text messaging is high among Generation Y, but is significantly lower among older generations. This suggests that the diffusion of the use of SMS technology is not yet fully completed in the United States. It also supports the initial aim of text-message marketing in the U.S. towards the youth market.

Swartz (2000) reported in an article in Wireless Review, "The teen and young-adult segment called Gen Y has the most spending power and independence of almost any other consumer segment today. And two-thirds of young adults rate communications as their highest priority." She also noted that SRI Media calls this segment the "heart of mobile communications megagrowth." These are also the consumers who are most likely to adopt new technology. Mucha (2004) also noted that $77 \%$ of young American consumers have access to a cell phone, and that $57 \%$ send text messages on a regular basis. Fifty-three percent of Generation Y text messages regularly, while 18\% use instant messaging, and 13\% use email and browse the web regularly (Fritchard, 2004). 
Although most commonly targeted toward the young, text-message marketing can also successfully target older adults. In an article by James (2002), its is suggested that "SMS campaigns for young consumers must be interactive, entertaining and delivered in teens' 'text language,' Meanwhile, marketers turning their attention toward the adult market are getting better results simply delivering practical and timely information" (James, 2002). This suggests that younger consumers seek the interactive response (two-way communication), while older consumers are simply looking for delivered information (one-way communication). James (2002) further notes that regardless of age, the two most important factors to text-message marketing success are permission and relevancy.

\section{THE FUTURE OF SMS IN THE U.S. AND ABROAD}

According to Dicklinger, Haghirian, Murphy and Scharl (2004), "mobile services offer companies powerful marketing potential via direct communication with consumers, anytime and anywhere." The potential value in reaching consumers on the go is extraordinary. From providing in-the-moment data such as driving directions, located-based promotions, movie times and such to building excitement, word of mouth transmission and brand recognition through two-way communication, text message marketing has value. By respecting the two most important factors in text message marketing success - relevant information and permission-based use (James, 2002) marketers should find consumers receptive to its use.

Information relevant to the user was one of James (2002) key text-messaging factors. In a study conducted by TNS Telecoms in 2005, wireless users were asked what wireless feature was of most interest to them. The largest percentage $-20 \%$ of respondents - wanted to receive local weather and/or traffic alerts through text messaging. This local content is often unavailable, but the research suggests it would be of value to wireless users (Burns, 2005). Marketers must be careful to research just what content is of value to users, and how to position their marketing messages alongside such content.

James (2002) also cautions that all communications via text-message marketing be permission-based. "The secret is in building the right kind of databases through an 'opt in' marketing program." Marketers generally provide opt-in service on the web site location. Users provide a cell phone number and sign-up for the text-based service. Some marketers use double opt-in which then reconfirms the user's commitment to the text-based program. All textmessages should offer a manner to opt-out of the service as well. Content should add value without bombarding the consumer with irrelevant messages (Direct marketing with unique interactive SMS system delivers response rates of $25 \%$ and more, 2004).

What's ahead for text-message marketing in the United States? As the cost of text messaging decreases, and as U.S. wireless users send more text messages, marketers will explore the role of text-message marketing in the overall marketing communications mix. Younger wireless users will be the likely recipients of the new text-message marketing efforts. Researchers will determine the content of interest for consumers, and communications agencies will scramble to determine the best way to integrate the technology into communications strategy. According to the Mobile Marketing Association (MMA), eMarketer predicts a short period of disenchantment with wireless around 2007, after companies throw money at text-message marketing in a feverish pitch to catch up. As the end of the decade approaches and text marketers find its place in the communications mix, eMarketer predicts a more mature use of this wireless technology (eMarketer report on wireless: February 2005, 2005). There is no doubt that the most significant advantage of this technology is in the ability to reach consumers out of the home. The "brand in hand" feature of wireless commercial communication is exciting and incredibly important to study as consumers' behavior shifts from a home-based communication model, to a mobile-based communication model.

\section{REFERENCES}

1. Altschul, M. (2003). Remarks of Michael F.Altschul senior vice president and general counsel Cellular Telecommunications \& Internet Association before the Federal Trade Commission, Spam Forum, May 1, 2003. [Online]. Available: http://www.ftc.gov/bcp/workshops/spam/supplements/altschul.pdf (8/06/04).

2. Burns, E. (2005). Wireless users want local content. Clickz.com. [Online]. Available: http://www.clickz.com/stats/sectors/wireless/article.php/3520196 (8/28/2005). 
3. Dickinger, Haghirian, Murphy, and Scharl (2004). An investigation and conceptual model of SMS marketing.

4. Direct marketing with unique interactive system delivers response rates of $25 \%$ and more (2004). BizCommunity.com. [Online]. Available: http://www.biz-community.com/Article/196/14/3395.html $(8 / 28 / 2005)$.

5. $\quad$ eMarketer report on wireless: February 2005 (2005). Mobile Marketing Association. [Online]. Available: http://www.mmaglobal.com/modules/content/index.php?id=54 (8/28/2005).

6. $\quad$ Fritchard, K. (2004). Gaming the teenybopper. Wireless Review. Vol. 21, Issue 5, p. 9.

7. Horror film viral send victims phone message (2005). Textually.org. [Online]. Available: http://www.textually.org/ textually/archives/2005/08/009699.htm (8/28/2005).

8. James, D (2002). Tough 'Cell.' Marketing News. January 7, 2002.

9. Lowry, T. (2001). Media's new on-the-go consumers. Business Week. [Online]. Available: http://www.businessweek.com/magazine/content/04_28/b3891012_mz001.htm (7/14/04).

10. Marketers discovering the "third screen." (2005). Textually.org. [Online]. Available: http://www.textually.org/ textually/archives/2005/07/009054.htm (8/28/2005).

11. May makes way for all time top text total (2005). Mobile Data Association Media Centre. [Online]. Available: http://www.text.it/mediacentre/default.asp?intPageId=843 (8/15/2005.

12. McGann, R. (2005). Generation Y embraces SMS. ClickZ.com. [Online]. Available: http://www.clickz.com/stats/sectors/wireless/article.php/3489776 (8/28/2005).

13. Mobile marketers turn to live assistance (2005). Textually.org. [Online]. Available: http://www.textually.org/textually/archives/2005/01/006905.htm (8/28/2005).

14. Mobinet Index \#3 (2001). ATKearney. [Online]. Available: http://www.atkearney.com/shared_res/pdf/ Mobinet 3 S.pdf. $(8 / 28 / 2005)$

15. Mucha, T. (2004). Young and upwardly mobile. [Online]. Available: http://www.business2.com/b2/ web/articles/0,17863,659808,00.html?cnn=yes $(7 / 14 / 04)$.

16. Newcomb, K. (2005). OMG BSB R GR8! Atlas OnePoint. [Online]. Available: http://www.clickz.com/ news/article.php/3527581 (8/28/2005).

17. No text please, we're American (2003). Economist. [Online]. Available: http://www.economist.com/ PrinterFriendly.cfm?Story ID=1683713 (9/11/2005).

18. Proceedings of the $37^{\text {th }}$ Hawaii International Conference on System Sciences. [Online]. Available: http://csdl2.computer.org/comp//proceedings/hicss/2004/2056/01/205610031b.pdf (8/15/2005).

19. Rendon, P. (2004). Does text sell? Marketing Magazine. Volume 109, Issue 15, p. 15.

20. Smart claims a first for text message response system to TV advertising (2005). Textually.org. [Online]. Available: http://www.textually.org/textually/archives/2005/01/006784.htm (8/28/2005).

21. SMS (2005). PCMag.com. [Online]. Available: http://www.pcmag.com/encyclopedia term/0\%2C2542\%2Ct\%3DSMS\&i\%3D51563\%2C00.asp (8/28/2005).

22. SMS campaign for launch of Harry Potter DVD in France (2004). Textually.org. [Online]. Available: http://www.textually.org/textually/archives/2004/12/006422.htm (8/28/2005).

23. SMS Marketing (2005). Brainstorm. [Online]. Available: http://www.brainstorm.co.uk/sms marketing.htm $(8 / 28 / 2005)$.

24. SMS marketing yields $15 \%$ response (2004). The Economic Times. [Online]. Available: http://www.economictimes.indiatimes.com/articleshow/502766.cms. (8/28/2005).

25. Srinivasan, L. (2004). SMS marketing: What's the writing on the wall? The Financial Express. [Online]. Available: http://www.financialexpress.com/fe full_story.php?content_id=57321 (8/28/2005).

26. Swartz, N. (2000). Talkin’ About Generation Y. Wireless Review. Vol. 17, Issue 20, p.54.

27. Text messaging (2005). PCMag.com. [Online]. Available: http://www.pcmag.com/encyclopedia_term/ $\underline{0,2542, \mathrm{t}=\text { text }+ \text { messaging } \& \mathrm{i}=52795,00 \text {.asp }}(8 / 28 / 2005)$.

28. Thompson, S. (2005). Kraft offers recipe downloads for iPods. AdAge.com [Online]. Available: http://www.adage.com/news.cms?newsId=45876 (8/28/2005).

29. TV ad text response (2005). Textually.org. [Online]. Available: http://www.textually.org/textually/archives/2005/07/009233.htm (8/28/2005).

30. Yuan, L (2005). Text messages sent by cellphone finally catch on in U.S. The Wall Street Journal. [Online]. Available: http://online.wsj.com/article/0,,SB112372600885810565,00.html (9/11/2005). 
31. 100 billion messages sent by UK's texting generation as texting hits all time high (2005). Mobile Data Association Media Centre. [Online]. Available: http://www.text.it/mediacentre/default.asp?intPageId=847 $(8 / 25 / 2005)$.

\section{NOTES}

